work and the directors of C. A. Parsons and Co., Ltd., for permission to publish this communication.
M. E. ZeIn Eudine
A. A. ZAKY
R. HAWLEY
M. C. Cullingford

Corona Group,

C. A. Parsons and Co., Ltd., Newcastle upon Tyne, 6.

${ }^{1}$ Ward, B. W., and Lewis, T. J., Brit. J. App. Phys., 14, 368 (1963). ${ }^{2}$ Cullingford, M. C., Zaky, A. A., Zein Eldine, M. E., and Hawley, R.,

${ }^{3}$ Schumann, W. O., Ann. Phys., 15, 843 (1932).

"Guizonnier, R., Rev. Gen. Elec., 68, 489 (1954).

'Croitoru, Z., Bull. Soc. Franc. Elec., 1, No. 6 (June 1960).

- Hawley, R., Nature, 196, 56 (1962).

' Forster, E. O., J. Chem. Phys., 37, 1021 (1962).

' Zein Eldine, M. E., and Tropper, H., Proc. Inst. Elec. Eng., 103, C, 35 (1956).

\section{Rheological Characterization and Incompressible Flow}

Is the published literature it is sometimes stated that a knowledge of two normal stress differences as a function of shear rato together with the viscosity shear rate relation and the condition of incompressibility is sufficient to characterize non-linear viscoelastic flow because the condition of constant volume gives another relationship between normal stresses.

Consider the stresses to be divided up in the following way:

$$
\tau_{i j^{\prime}}=\tau_{i j}-p \delta_{i j} \quad(i, j=1,2,3)
$$

where $p$ is an arbitrary hydrostatic pressure and $\delta_{i j}$ is the Kronocker $\delta$,

$$
\begin{aligned}
\delta_{i j} & =0 \text { if } i \neq j \\
& =1 \text { if } i=j
\end{aligned}
$$

If, for example, we consider a material in simple shearing motion $\left(u_{1}, 0,0\right)$. where $u_{1}=k x_{2}$ in the co-ordinate system $\left(x_{1}, x_{2}, x_{3}\right)$ and the normal stresses are $\left(\tau_{11}, 0,0\right)$, which is a definite possibility. The constant volume condition for zero $p$ is :

$$
\tau_{i i}=0 \quad \text { liquid }
$$

but this violates the assumption about the stress distribution and does not apply.

In some work the stress is divided up in the following way:

$$
\tau^{\prime}{ }_{i j}=\tau^{\prime \prime}{ }_{i j}-\frac{1}{3} \tau_{k k} \delta_{i j}
$$

and $\tau^{\prime \prime}{ }_{i i}=0$ by definition, but this does not give additional physical information as is sometimes supposed.

In view of the foregoing no less than three functions of the normal stresses are required in general plus the viscosity-shear rate relation if volume changes are ignored. But the volumetric strain gives a further relation between the normal stresses.

Department of Civil and Mechanical Engineering,

J. Harris

Queen's College, Dundee.

\section{GEOLOGY}

\section{Occurrence of Karroo System Sediments in Ethiopia}

I wish to comment on Dr. P. A. Mohr's recent communication", "Occurrence of Karroo System Sediments in Ethiopia".

Two of Mohr's conclusions are extremely far-reaching from a palæogeographic point of view in that the Karroo 'System', essentially a southern African group of formations, is extended well north of the equator into northeast Africa. However, before the following conclusions are accepted by African stratigraphers, they must jbe supported by more evidence to prove that: (I) the preAdigrat sediments recently discovered resting on the
Basement Complex in the Blue Nile (Abbai) Canyon in Central Ethiopia are Permo-Triassic in age; (2) the newly discovered sediments are of Karroo type.

Essentially what Mohr and Jepsen have found is a group of sediments of pre-Adigrat age which were deposited in valleys cut in the Basement Complex, which itself had been planated in pre-Adigrat times. In my opinion all that can be said at present about these sediments in terms of international ehronology is that they are postBasement Complex and pre-Bajocian in age.

In the absence of fossils, and no palæontological evidence for the pre-Adigrat beds is given in the communication, is it reasonable to assume that: (1) the pre-Adigrat beds are Permo-Triassic in age; and (2) the surface on which the Adigrat formation was laid down was formed in Late Palæozoic time ?

The sub-A.digrat regional surface could equally well be much older than Late Palæozoic, and lithological similarity is not proof of age, especially when the deposits are correlated with the Duruma formation which at its nearest point is about 900 miles away.

Also it should not be forgotten that the type area of the Karroo 'System' is in Cape Province, Orange Free State, and Natal where the composite section is more than $35,000 \mathrm{ft}$. thick; that the Karroo ranges in age from Carboniferous to Lowor Jurassic; and that it consists of a great variety of rocks including tillites, volcanics and most common types of sediments.

Therefore, to suggest that pre-Adigrat "thin bedded bluish-grey calcareous mudstones overlain by massive dark grey sandstone beds" are of Karroo type, and in addition are Permo-Triassic in age, is unjustifiable in my opinion.

Clearly, then, before a Karroo label, as the title of the letter implies, is attached to the Blue Nile pre-Adigrat sediments, and before epeirogenic movements and erosional cycles of regional significance are dated, palæontological evidence must be provided to date these events.

Department of Geology,

A. J. WHITEMAN

University of Khartoum,

Khartoum, Sudan.

${ }^{1}$ Nature, 199, 1086 (1963).

To ascribe the pre-Adigrat beds of the Abbai basin to the Karroo System has so far been basod, within the limits of certainty given in my first communication on denudational chronology, lithology, and relationship to the Mesozoic marine horizons. Intended micro-palæontological and isotopic age-determination work on these beds should further clarify their stratigraphical position.

The end-Palæozoic age of the termination of peneplanation of the Basement rocks in northern, central and eastern Ethiopia has been accepted by most previous workers, ${ }^{\mathbf{1 , 2}}$, and Prof. Whiteman presents no evidence to support the doubts he now casts on this dating.

Prof. Whiteman considers that the immediately evident disparity between the type Karroo System rocks and the pre-Adigrat sediments, in terms of thickness, variety of lithology, and spatial separation, is such that suggestion of a correlation of the latter with the Duruma formation of coastal Kenya is unjustifiable. In this respect it is interesting to note, for example, the recent attribution ${ }^{3}$ to the Karroo System of such distant and minor sedimentary outcrops as the Ecca-type shales of Uganda and the Mansa Guda clastics of northern Kenya. While intimacy of spatio-temporal features of sediments is important in making correlations, it is not eritical.

Haile Selassie I University,

P. A. MOHR

Addis Ababa, Ethiopia.

1 Dainelli, G., Geologia dell'Africa Orientale (Realc Accademia, Roma, 1943). ${ }^{2}$ Mohr, P. A., Geology of Ethiopia (Addis Ababa, 1962).

${ }^{3}$ Saggerson, E. P., The Physiology and Geology of East Africa (Hawkins, Ltd., Nairobi,' 1962). 